\title{
Political Rationales for Homeschooling
}

The rationale to homeschool for political reasons can derive from many political philosophies and justifications - often, more than one. For many, public schools represent governmental overreach into our personal lives, student histories, medical and health records, financial records of the family, etc. Public schools, for some, represent an effort to control the masses through indoctrination into political ideals (e.g., Marxism, multiculturalism, diversity, etc.) and with scientific ideas that are interpreted as an affront to religious doctrines (e.g., evolution, climate change, sex education, etc.) but are perceived not singularly as religious issues but also political control. In the same vein, some see public schools as a challenge to notions of rugged individualism where it is - or ought to be - everyone for themselves (think stereotypical nostalgic views of Western-progressing pioneers). Circling back to the consideration of education understood as a public good that benefits the collective or as a private individualistic good, many understand homeschooling as a possibility to enact their political ideology that individuals (understood as individual families) are responsible for, and only unto, themselves. Within many circles, phrases such as "public education" and "public schools" are replaced with "government-controlled schools" to center the primary animosity towards public schools and favor of homeschooling as a political stance against what is seen as Statism and government overreach. Brian Ray (2016) suggests that,

Whether the reader holds to a more statist or democratist [sic] worldview versus a classical liberal (cf. Rothbard, 1999) or biblical scriptural worldview will determine his or her thoughts about homeschooling in general and opinion about, in particular, whether the state should control private homeschooling. (p. 19)

A significant portion of this conversation is couched in the false dichotomy of "capitalism versus socialism, or freedom versus statism" (Rand, 1967, as cited inMacLean, 2017, p. 91). For others, such as the HSLDA, they oppose "any legislation that would increase regulation of homeschoolers" (HSLDA, n.d.) as any government oversight of homeschooling is understood, politically, as anathema to the rationale of homeschooling. This may also explain why we continue to know so little about who is homeschooling and for what purposes. The data that the National Center of Education Statistics - a government agency - notes

(C) KONINKLIJKE BRILL NV, LEIDEN, 2021 | DOI: 10.1163/9789004457096_004 
that the "non-response rate [for its surveys] is higher for the homeschool survey than others" (Silva, 2018). While NCES is not a partisan agency, it is, by extension, part of the government and a lack of engagement can be part of the disposition towards eschewing government "intrusion" into private lives (see, for instance, Westover, 2018).

While Lubienski and Brewer argued that the public has a "responsibility to ensure a diverse socialization that is innate and necessary within a democracy" (Lubienski \& Brewer, 2014, p. 144), homeschooling advocate Brian Ray of the NHERI pushed back suggesting that Lubienksi and Brewer,

imply that homeschooling that is free of state control is a threat to their statist belief system. That is, Lubienski and Brewer want to use the state to control education to mold children's minds and worldviews to be socialized according to their personal vision of the good and right society. Further, neo-Marxist hopes show up in their concern that homeschooling will not right the wrongs - as they claim state-run schooling does - of certain "social inequities" that come with the particular family into which certain children are born (e.g., Lubienski \& Brewer, p. 145). (Ray, 2016, p. 19)

In alignment with a commitment to libertarian rugged individualism, Ray claims that the aim of public schools to provide all students with a diverse socialization experience (which would include interactions with myriad of types of students and a broad curriculum), is tantamount to state-based control and Marxist indoctrination. And while I have been clear here that public schools have not fully realized its aim to provide equitable opportunities for all students, the point remains that public schools have the best possibility and opportunity for such goals. In Ray's summary of our claim above, he wrongly claims that such dispositions towards the opportunities as they exist between public schools and homeschooling amounts to Marxism. Our claim, in more detail, was,

Finding roots in the neo-liberal ideologies of Milton Friedman, homeschool advocates and parents often view state-run schools as naturally ineffective and inefficient. Yet, state-run schools are likely more equipped to promote equality and diversity - a central concern of a pluralistic democracy - rather than the homogeneous environment of the family. Moreover, while there is some truth in views that government institutions can limit opportunities for some groups, state-run schools serve as a source of liberation for some groups, expanding opportunity for many 
who would not otherwise have advantages from their home lives and providing and creating a sanctuary for those in more oppressive home environments. (Lubienski \& Brewer, 2014, p. 145)

Put plainly, if the aim of our society is the maintenance of a pluralistic democracy, then by its very definition, homeschooling - which is nearly entirely homogeneous in nature - is less suited than public schools - which is more heterogeneous in nature - at facilitating the means by, and through, which such a society is maintained. But, the concept of a pluralistic democracy is specifically anathema to some of the politics notable among the homeschooling culture. Finding Biblical justification for slavery allowed Protestant evangelicals such as Rushdoony - a "powerful advocate for the Christian and homeschool movements across America" (Stewart, 2019, p. 122) - to justify political stances that reinforced racial hierarchies in society and the schools that reinforced them by pushing back against pluralism. Specifically,

Rushdoony amplified the message, arguing that the "government school" has "leveled its guns at God and family." "Liberal education is inevitably pluralistic," he lamented. "It would follow that Southerners are clearly wrong in resisting integration of white and Negro pupils." The implication here was that they were, in fact, right to have resisted integration. In Rushdoony's view, there was nothing wrong in principle with segregation. (Stewart, 2019, p. 118)

In considering the reasons that many homeschooling parents give to why they homeschool, Homeschooler and author of the book "Socialize Like a Homeschooler" and blogger at "Hifalutin Homeschooler" Jennifer Cabrera argues that many homeschooling families have, for too long, answered such questions from a position of political correctness often responding with, "It's what is best for our family." Couched in the conservative disposition of animus towards "PC language," Cabrera suggests that such answers are a "cop out" that should be avoided. What she suggests is that homeschooling parents be more honest and proud of their choice to homeschool that, in her case, was rationalized by wanting to be in control of their family's schedule, ensuring that their children were not exposed to bullying, school shootings, societal moral decline, and learning to think rather than "regurgitate facts for a test" while allowing the family to "follow God's instruction to educate our kids to live a Christian life" (Hifalutin Homeschooler, 2018). While Cabrera includes multiple "honest" reasons for why families may homeschool, much of the justifications are presented in response to what is understood as bad government. She claims 
that "homeschooling continues to grow as public education continues to spiral downward and our government becomes more contemptuous of the family unit ..." (Hifalutin Homeschooler, 2018). For Cabrera, the "non-politically correct" reasons that she and others homeschool are:

1. We like to be in control of our schedule and what values our kids learn.

2. To ensure our kids are loved and safe from bullies and school shootings.

3. We want our kids to get a top quality, personalized education.

4. So our kids will learn to think and reason, not just regurgitate facts for a test.

5. Our kids need time with their father, who they would otherwise never see.

6. It is best for our family.

7. The time with our kids will go by fast and we want to be together.

8. We want to follow God's instruction to educate our kids to live a Christian life.

9. Freedom!

10. We have seen the downward spiral of the education system, societies morals, and the family unit, and we don't want it influencing our children. (i.e. We've seen the village ...). (Hifalutin Homeschooler, 2018)

The term "values" in the first rationale is quite broad. While it can include religious values, those are listed separately later in the list. As a result, it is not beyond the scope of reason that values here mean political values. Other rationales above such as "Freedom!," understandings of policies that may influence changes in the education system that are seen as threatening morals, and testing all reflect political decisions. Of the "10o Reasons to Homeschool Your Kids," below are those that fall under the realm of political rationale:

\section{Political/Economic}

1. Homeschooling has wide bipartisan appeal.

2. Religious freedom may be important to many homeschooling families, but it is not the primary reason they choose to homeschool. "Concern about the school environment, such as safety, drugs, or negative peer pressure" is the top motivator according to federal data.

3. Fear of school shootings and widespread bullying are other concerns that are prompting more families to consider the homeschooling option. 
4. Some parents choose homeschooling because they are frustrated by Common Core curriculum frameworks and frequent testing in public schools.

5. It will also prevent schools from surreptitiously collecting and tracking data on your child's mental health.

6. And you can actually enjoy lunch with them rather than being banned from the school cafeteria.

7. Your kids don't have to walk through metal detectors, past armed police officers, and into locked classrooms in order to learn.

8. You can avoid bathroom wars and let your kids go to the bathroom wherever and whenever they want-without raising their hand to ask for permission.

9. Schooling was for the Industrial Age, but unschooling is for the future.

10. With robots doing more of our work, we need to rely more on our distinctly human qualities, like curiosity and ingenuity, to thrive in the Innovation Era.

11. Today's teens aren't working in part-time or summer jobs like they used to. Homeschooling can offer time for valuable teen work experience.

12. It can also provide the opportunity to cultivate teen entrepreneurial skills.

13. By forming authentic connections with community members, homeschoolers can take advantage of teen apprenticeship programs.

14. Some apprenticeship programs have a great track record on helping homeschoolers build important career skills and get great jobs.

15. Homeschooling could be the "smartest way to teach kids in the 21st century," according to Business Insider.

16. But college doesn't need to be the only pathway to a meaningful adult life and livelihood. Many lucrative jobs don't require a college degree, and companies like Google and Apple have dropped their degree requirements.

17. In fact, more homeschooling families from the tech community in Silicon Valley and elsewhere are choosing to homeschool their kids.

18. Some of these hybrid homeschool programs are public charter schools that are free to attend and actually give families access to funds for homeschooling.

19. Other education choice mechanisms, like Education Savings Accounts (ESAs) and tax-credit scholarship programs, are expanding to include homeschoolers, offering financial assistance to those families who need and want it. 
20. Some states allow homeschoolers to fully participate in their local school sports teams and extracurricular activities.

21. Your homeschooled kids will probably be able to name at least one right protected by the First Amendment of the US Constitution, something 37 percent of adults who participated in a recent University of Pennsylvania survey couldn't do.

22. Research suggests that homeschoolers are more politically tolerant than others.

23. In spite of ongoing efforts to regulate homeschoolers, US homeschooling is becoming less regulated.

24. That's because homeschooling parents are powerful defenders of education freedom.

25. Homeschooling is one way to get around regressive compulsory schooling laws and put parents back in charge of their child's education.

26. It can free children from coercive, test-driven schooling.

27. It is one education option among many to consider as more parents opt-out of mass schooling.

28. Homeschooling is the ultimate school choice.

29. It is inspiring education entrepreneurship to disrupt the schooling status quo.

3o. And it's encouraging frustrated educators to leave the classroom and launch their own alternatives to school.

31. Homeschooling is all about having the liberty to learn. (Adapted from McDonald, 2019)

As an overarching concept, a political rationale to homeschool takes on a uniquely anti-democratic disposition. Moreover, homeschooling is, primarily, a function of isolation and individualization. Homeschooling parents want to isolate their children against what they see as "conflicting cultural values" (Bartholet, 2019, p. 9)

One small, but notable, aside of the homeschooling for political rationales includes school funding. Specifically, there are many efforts by those who homeschool to lobby for state-based policies that provide homeschooling families some type of funding for their choice. These homeschooling vouchers or tax credits are designed to provide funding (directly or indirectly) to families who homeschool. Similar to a school voucher that provides government funding to families to send their children to private schools, similar policies that provide funding for homeschooling families redirect tax dollars away from public schools to support homeschoolers. In the event that the funding 
exceeds the individual family's tax contribution, the additional funds are paid for by other citizens. For vouchers, as was the case in 2016, the average cost to educate a student in Georgia was $\$ 9,769$. Providing the full amount to be used as a publicly-funded subsidy to offset the cost of private school tuition would require tax money paid by approximately six to seven other families as the median property tax paid by Georgians (and where the bulk of education funding derives) was $\$ 1,346$. At present, there are only three states that provide state public tax payer money to support private homeschooling: Illinois, Louisiana, and Minnesota (Southeast Homeschool Expo, n.d.).

While some families homeschool out of explicit political ideologies (see, for example, Westover, 2018), the religious orientation of many Protestant Evangelical Christians are interwoven with political aims and dispositions. As noted in the previous chapter, the aim of many religious homeschooling families is to simultaneously protect their children from the interpreted evils of secular public school but also to "train up" a future generation that will expand the role of this narrow Christianity throughout public schools and government. An example of this religion/politics partnership is the Ron Paul Curriculum. Paul, a notoriously libertarian U.S. Congressman whose son, Rand Paul carries on in his legacy, is staunchly anti-government despite being, in effect, a government employee. The Ron Paul Curriculum is "a homeschooling program with an emphasis on 'the Biblical principal of self-government and personal responsibility which is also the foundation of the free market economy" (Stewart, 2019, p. 119). This religious and political partnership aims to "get busy in constructing a Bible-based social, political, and religious order which finally denies the religious liberty of the enemies of God" (Stewart, 2019, p. 119). In this view, school curriculum and practices that are not aligned with a specific interpretation of the Bible are considered evil and any type of regulations on unfettered free-market capitalism is understood as going against God. In this logic, as it were, God is a fan of unregulated capitalism, meritocracy where individuals pull themselves up by their own bootstraps, and where any policy, practice, or content knowledge that does not reinforce such narrow political or religious doctrine is classified as "the enemy." Though, not all arguments in favor of homeschooling are overtly religious. Reason - the libertarian magazine - often publishes stories in support of school choice and occasionally holds up homeschooling as an ideal form of schooling that is superior to the "government controlled" public schools (Tuccille, 2019). While the rationales given often echo claims of efficiency and effectiveness like those explicated in Chapters 6 and 7, many times the rationale is simply that any form of schooling - and any form of anything - that is not affiliated with some form of government is preferred for the sake of preferring markets over collective 
government. Moreover, this political disposition is often wedded to specific religious dogmas as,

In the drive for homeschooling and the privatization of public education; in the providential history of Christian nation mythologizers; in their insistence that public officials be guided by a "biblical worldview"; in the unabashed commitment to the subordination of women, part of the order and structure of the universe as God intended; in the fusion of the bible with libertarian economics - eve in their arguments for gun rights and against universal health care - today's Christian nationalists follow the logic, if not necessarily the theology, laid down by Rushdoony. (Stewart, 2019, pp. 122-123)

In sum, while not all homeschooling families chose to keep their children at home as a manifestation of their political affinity, many do and such dispositions are often aligned with a very specific religious outlook on policy, practice, curriculum, pedagogy, and society. As Stewart suggested, "what they actually oppose is simply secular, democratic government, whereas what they invariably support is religious or theocratic government" (Stewart, 2019, p. 124). As argued by Cynthia Dunbar (Dunbar, 2008), the homeschooling parent and former Chair of the Texas Board of Education, Christian homeschooling and other forms of school choice are necessary to prevent the spread of liberalism and are vital to establishing the United States as a theocratic government singularly oriented to the Protestant Evangelical worldview.

\section{References}

Bartholet, E. (2019). Homeschooling: Parent rights absolutism vs child rights to education \& protection. Arizona Law Review, 62(1), 1-80.

Dunbar, C. (2008). One nation under god: How the left is trying to erase what made us great. HigherLife Publishing.

Hifalutin Homeschooler. (2018). 10 honest reasons parents choose to homeschool: And the politically correct defense we hide behind. Retrieved March 1, 2020, from https://hifalutinhomeschooler.com/1o-reasons-parents-homeschool/

HSLDA. (n.d.). Education tax credits. Retrieved March 28, 2020, from https://hslda.org/ content/docs/nche/Issues/T/Tax_Ed_Credits.asp

Lubienski, C., \& Brewer, T. J. (2014). Does home education "work"? Challenging the assumptions behind the home education movement. In P. Rothermel (Ed.), International perspectives on home education: Do we still need schools? (pp. 136-147). Palgrave. 
MacLean, N. (2017). Democracy in chains: The deep history of the radical right's stealth plan for America. Penguin Books.

Ray, B. D. (2016). Introduction to recent changes and research in us homeschooling. In B. S. Cooper, F. R. Speilhagen, \& C. Ricci (Eds.), Homeschooling in new view (2nd ed., pp. 3-28). Information Age Publishing.

Silva, E. (2018). The state of homeschooling in America. Retrieved March 30, 2020, from https://psmag.com/education/the-state-of-homeschooling-in-america

Southeast Homeschool Expo. (n.d.). What can homeschoolers deduct on their taxes? Retrieved March 1, 2020, from https://www.southeasthomeschoolexpo.com/ tax-deduction-for-homeschoolers/

Stewart, K. (2019). The power worshippers: Inside the dangerous rise of religious nationalism. Bloomsbury Publishing.

Tuccille, J. D. (2019). Homeschooling produces better-educated, more-tolerant kids. Politicians hate that. Retrieved February 17, 2020, from https://reason.com/2019/o1/22/ homeschooling-produces-better-students/

Westover, T. (2018). Educated: A memoir. Random House. 